Article

\title{
Changes in Income Structure in Frontier Villages and Implications for REDD+ Benefit Sharing
}

Takayuki Kurashima ${ }^{1, *}$, Toshiya Matsuura ${ }^{1}$, Asako Miyamoto ${ }^{1}$, Makoto Sano ${ }^{1}$, Bora Tith ${ }^{2}$ and Sophal Chann ${ }^{2}$

1 Department of Forest Management, Forestry and Forest Products Research Institute, 1, Matsunosato, Tsukuba, Ibaragi 305-8687, Japan; E-Mails: matsuu50@affrc.go.jp (T.M.); asakom@affrc.go.jp (A.M.); masakoto@affrc.go.jp (M.S.)

2 Institute of Forest and Wildlife Research and Development, Forestry Administration, Street 1019, Phum Rongchak, Sankat Phnom Penh Thmei, Khan Sen Sok, Phnom Penh, Cambodia; E-Mails: tithbora@yahoo.com (B.T.); sophal.chann@yahoo.com (S.C.)

* Author to whom correspondence should be addressed; E-Mail: kurakura@affrc.go.jp; Tel.: +81-29-829-8313; Fax: +81-29-873-3720.

External Editor: Eric J. Jokela

Received: 5 August 2014; in revised form: 13 November 2014 / Accepted: 18 November 2014 / Published: 24 November 2014

\begin{abstract}
A methodological characteristic of the REDD+ scheme is that it attempts to reduce deforestation by rewarding communities that change problematic land use practices. This has led to discussions on benefit sharing. This article focuses on incentives for alternative land use practices among village members living in frontier areas, especially in relation to support for sustainable land use and people's livelihoods, and clarifies the issues that REDD+ projects are likely to face in this context. Although some documents regarding REDD+ projects have mentioned support to encourage such incentives, insufficient consideration has been given to the realities of the changes in frontier communities. REDD+ projects are unlikely to motivate members to embrace alternative land use practices if support or benefit sharing does not match members' expectations. Here, we examine the changes in household $(\mathrm{HH})$ income and structure, as well as in livelihood activities, experienced by Cambodian frontier villagers living at the site of a planned REDD+ project. During the nine years compared in this study, the frontier villages experienced broad and imbalanced changes in $\mathrm{HH}$ income owing to the rapid expansion of the cultivation of cash crops. Our results indicate that benefit sharing or support inevitably becomes more difficult
\end{abstract}


and challenging in frontier areas than in areas where subsistence production systems still predominate, although such frontiers could, in theory, yield maximum returns with regard to forest carbon balance if the REDD+ projects addressed benefit sharing and support and came to fruition.

Keywords: REDD+; benefit sharing; incentive; frontier community; household income; production system; land use; Cambodia

\section{Introduction}

The "reducing emissions from deforestation and forest degradation in developing countries; the role of conservation, sustainable management of forests and enhancement of forest carbon stocks in developing countries" (REDD+) mechanism attempts to reduce deforestation by compensating or rewarding governments, individual agents and communities that change influential policies and land use practices along with implementing some other core measures. Appropriate benefit distribution to eligible stakeholders is an essential element of REDD+, which has spurred many discussions among academics and international aid societies on benefit sharing [1-10]. Of the important topics relevant to REDD+ benefit sharing, this article focuses on incentives for alternative land use practices among community members, especially those who earn their livelihoods in frontier areas, and discusses the issues that REDD+ projects are likely to face in such areas in this context.

"Frontier areas" the focus of this article, comprise the second of three forest-transition stages proposed by Angelsen and Rudel [11]: (1) core forests; (2) frontier areas; and (3) forest-agricultural mosaics. Partly based on Chomitz et al. [12] and Pacheco et al. [13], Angelsen and Rudel [11] suggested that frontier areas have the following characteristics: the population density is low to medium; market access is medium; poverty differs between groups; land tenure is insecure; governance is tenuous; and the opportunity cost of forest conversion is medium to high. Chomitz et al. [12] organized forests (land) over the world in terms of spatial typology, instead of considering transitional changes, defined "frontier areas" as "frontier and disputed areas" and characterized them as areas where the pressures for deforestation and degradation are increasing and agricultural land is expanding. These frontier areas are worthy of examination by a REDD+ project, because they can, in theory, yield significant returns with regard to the forest carbon balance if the project addresses benefit sharing and comes to fruition.

It is important that incentives induce stakeholders to change their behaviors [9]. Furthermore, appropriate benefit sharing is crucial for creating and upholding such incentives [10]. Here, we apply the definition offered by $\mathrm{PwC}$ (PricewaterhouseCoopers) [7] for the incentive types distributed through the benefit-sharing scheme, as that definition can encompass REDD+ projects at frontiers. According to PwC [7], incentives for specific actions in the forest sector, including REDD+, consist of three types of benefits, in addition to forest rent: (1) compensation for opportunity costs; (2) support for sustainable land use and livelihoods; and (3) support for forest governance and institutional development. Of these three types, the cost evaluation of opportunity cost compensation, particularly for local villagers, is difficult in frontier areas, as large parts of each frontier are located across and in national forest land, and much of the cultivated and uncultivated land is not regulated by clear legal property rights $[3,5,8,13]$. 
Consequently, the likely incentives for de facto occupying farmers and potential deforesters in frontier areas comprise the benefits of the second and third types. Moreover, especially during the early stages, support for sustainable land use and people's livelihoods has a higher priority for community members in these areas, because the members have little motivation to develop institutions or new forest governance if they cannot benefit from support for alternative land use practices.

Many studies regarding REDD+ benefit sharing have taken up macro-subjects, such as the entire structural framework and distributional rationale of stakeholders at international, national and local scales. Few studies, with certain exceptions [3,8], have focused on micro-subjects, such as support for sustainable land use and people's livelihoods at the local village level. Additionally, even these studies did not cover the concrete content of support and its supposed potency, but instead, cited the types of villagers who were eligible for REDD+ benefits [8]. For concrete support at the local level, we analyzed a REDD+ project design document [14], where the site was situated in a national reserve and employed the farming activities of local people as a deforestation driver, referring to REDD+ project review reports $[15,16]$, which organized 35 design documents, for the selection of relevant documents. The design document helped us to understand the support that was intended to incentivize community members' land use, as the concrete support items, e.g., agricultural techniques, were described [14]. However, we could not judge whether the support actually did encourage the members to change their behaviors, because inadequate information on members' livelihoods and incomes was included.

As with other development assistance programs, to support sustainable land use and people's livelihoods, REDD+ projects need to consider the existing situation and historical background when providing effective assistance for recipient communities. Even if REDD + project developers unilaterally consider the offered assistance to be valuable for the livelihoods of community members, this is unlikely to motivate the majority of members to embrace alternative land use practices if the type and amount of assistance or benefit sharing for each member does not meet expectations. Although most communities will not decline assistance of any type, the likelihood of achieving desired responses, i.e., the majority of members refraining from further forest land clearing and arable land expansion, depends largely on the gain from support in the REDD+ project compared with possible current and future gains from ongoing and intended land use practices. Thus, accurate information on communities and insights based on such information need to be accumulated and developed to encourage truly functional assistance by REDD+ projects.

To focus on a key reality that has an enormous influence on the reactions of REDD + recipient communities, this article notes and explores the changes in income and income structure, as well as in livelihood activities, that frontier households (HHs) experience. Some reports have elucidated farmers' recent income situation at REDD+ project sites [17-19], but few studies have investigated changes in income and livelihood among members of frontier communities. The reality of changes in income and income structure will provide background information for forecasting the value and type of assistance that the majority of villagers will be inclined to accept to comply with REDD + goals. These results will help to identify the tradeoff in REDD+ benefit sharing in frontier areas, which can, in theory, yield the maximum returns with regard to forest carbon balance. 


\section{Materials and Methods}

\subsection{Study Site and Land Use Changes}

We examined data obtained from central Cambodia, specifically three Khmer villages in the eastern part of Kampong Thom Province (Figure 1). We selected this site for the following reasons: a REDD+ project was prepared in 2013 when planning the Prey Long (PL) protection forest zone; cultivated land for commercial crops has been expanding rapidly over the past several years; and an $\mathrm{HH}$ income and livelihood study was conducted in the area 10 years ago by McKenny et al. [20], providing empirical data for temporal comparisons of the $\mathrm{HH}$ incomes of the three villages.

Figure 1. Cambodia, the east part of Kampong Thom Province, and the research site.

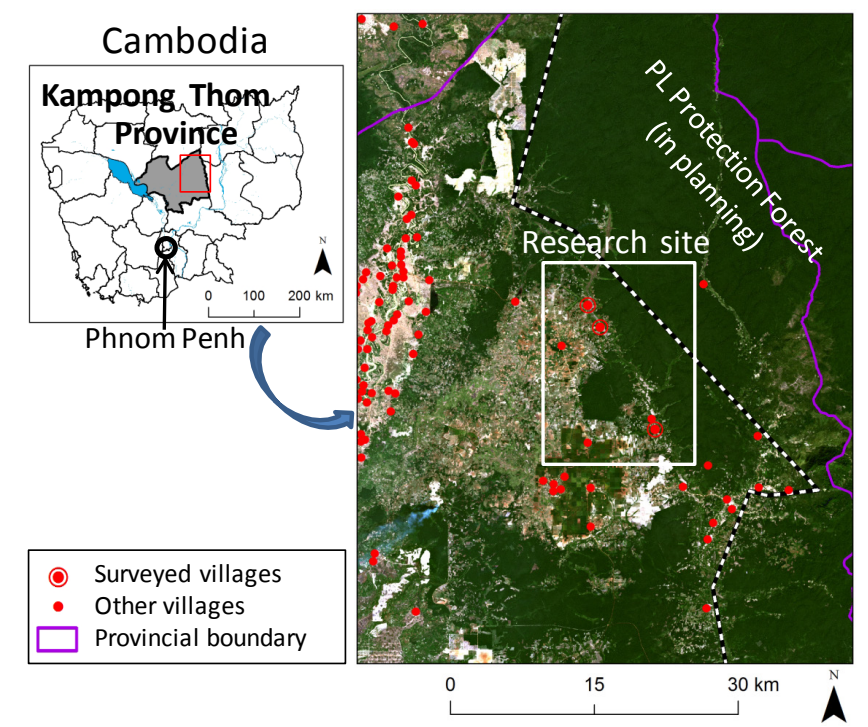

Source: true-color band combination from Landsat 8, taken 12 January, 2014. Forestry Administration, Kampong Thom.

Drastic land use/cover changes can be identified from two satellite images taken in the dry seasons of 2003 and 2014 (Figure 2). Black and green areas indicate forest, and white and light red areas indicate cleared land. These images show the extensive forest clearing and arable land expansion that occurred around the three villages during the decade. Figure 3 shows the changes in the cultivated areas of four main crops in the entire commune where the three villages are located. Expansion of cassava cultivation, in particular, was quite significant, and this trend was not exceptional in the land use around the three villages.

Leading contributors to these drastic land use changes, especially around the three villages, during the past decade were, according to various sources of information that included villagers, both old-settlement and new immigrant farmers who were living in the villages. However, large-scale developers were responsible for the deforestation of vast natural forest areas outside the villages' area, too $[21,22]$. In the mid-1990s, much of this area was demarcated as a logging concession zone by the Cambodian government, and part of the forest was selectively logged by contractors until 2001. Subsequently, some degraded and intact upland forests, which had been originally or newly occupied or 
bought from local occupants, had been opened up by old- and new-settlement farmers to grow cash crops along with a small quantity of upland rice for home consumption.

Figure 2. Land cover change from early 2003 (A) to early 2014 (B).

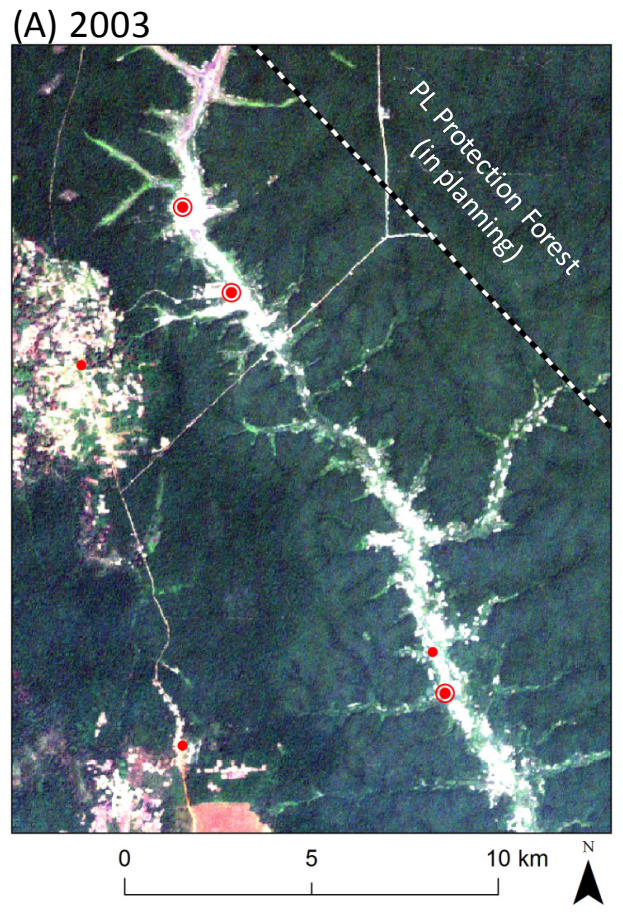

(B) 2014

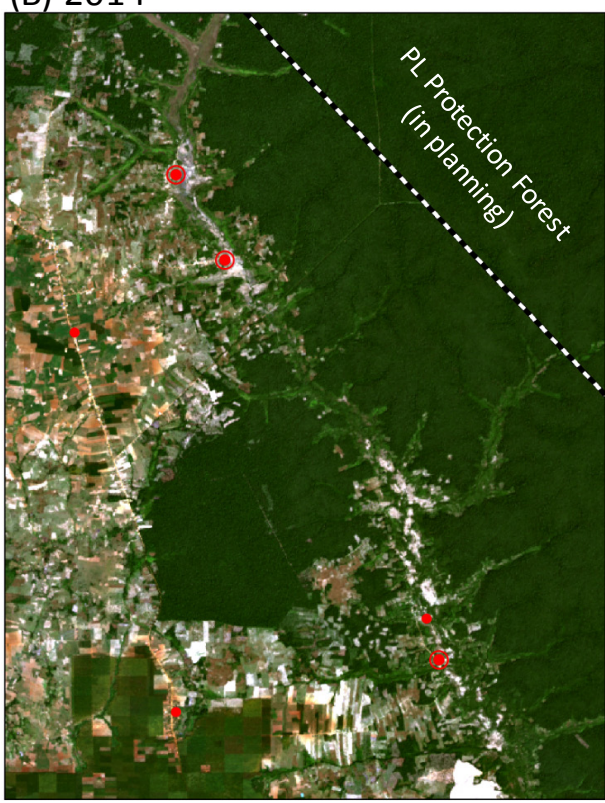

O Surveyed villages

- Other villages

Source: true-color band combination from (A) Landsat 5 TM, taken 7 February, 2003; and (B) Landsat 8, taken 12 January, 2014. Forestry Administration, Kampong Thom.

Figure 3. Changes in the areas of cultivation of four main crops in the commune where the research site is located.

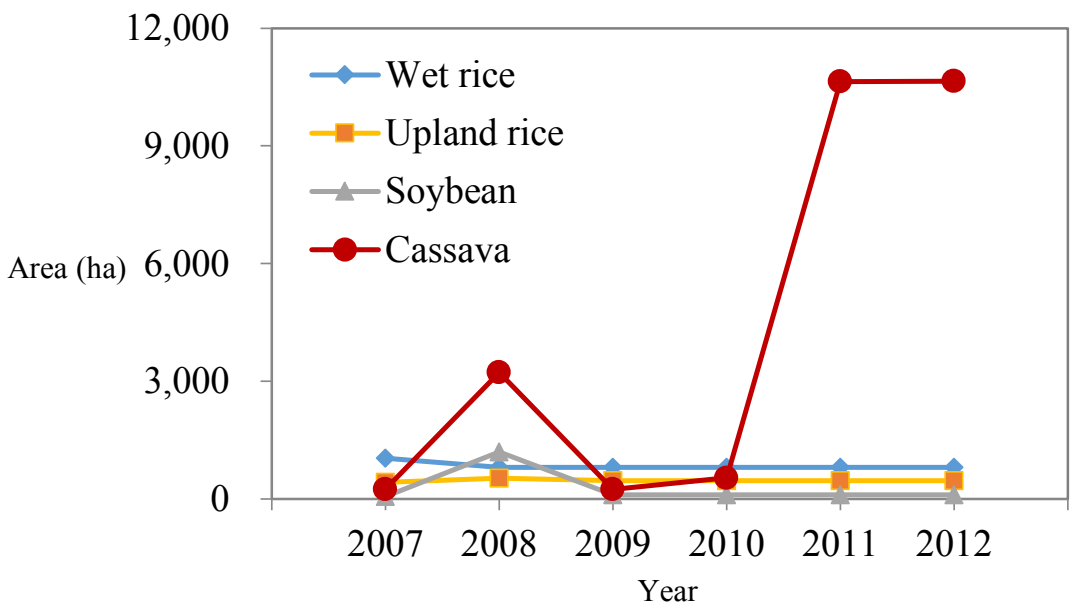

Source: Ministry of Planning, Community Database, 2007-2012.

\subsection{Data Collection, Data Interpretation Methodology and Outline for This Article}

The data for this article were obtained primarily from the HH survey conducted in the latter half of 2013. From the HH survey of 2013, we collected information on livelihood activities during 2012, 
incomes in the same year, production resources, such as cultivated land, and other necessary matters, e.g., when and how each HH had obtained its land. The interviews targeted the head and/or a secondary head of each $\mathrm{HH}$, aged 30-70 years. Additionally, we conducted interviews in the home of each $\mathrm{HH}$, because of the advantages that this setting presented, such as the opportunity to observe informants' lifestyles. In total, 146 randomly chosen HHs, accounting for more than $30 \%$ of the HHs in each of the three villages (62 of $198 \mathrm{HHs}, 54$ of $143 \mathrm{HHs}$ and 30 of $94 \mathrm{HHs}$, respectively), were surveyed for this study. This percentage of households is comparable to that surveyed by McKenny et al. [20], although that study surveyed only $85 \mathrm{HHs}$, because there were fewer HHs in 2003 . The number of HHs in the study villages increased by 66\%, from 262 to 435, between 2003 and 2012, due to increases in population and immigration from other districts. In addition to these $\mathrm{HH}$ members, village leaders were interviewed in 2013 regarding villagers' production systems, villagers' livelihoods and the history of land use around the villages.

To facilitate comparisons between the two surveys, many questions were similar to those used by McKenny et al. [20]. Similarly, some data accounting methods, e.g., factoring the value of rice produced for $\mathrm{HH}$ consumption into $\mathrm{HH}$ income, were used here to correspond with the data interpretation by McKenny et al. An exception was the calculation of fish, fuel wood and other non-timber forest products (NTFPs) used for HH consumption. McKenny et al. included these outputs in HH income calculations, although they noted that their counting methodology involved uncertainty [20]. We could not do so, due to difficulties with data collection and expected data uncertainties. This may have resulted in lower calculated incomes in our study compared with those of McKenny et al. [20], particularly for other NTFPs, as the quantity consumed within HHs was not counted in our study. However, this is not a fatal flaw for temporal comparisons due to the small amounts of these outputs consumed within HHs compared with the overall incomes, as explained by McKenny et al. [20], and the comments from village leaders that other NTFP collection had generally declined compared with a decade ago. We include our questionnaire in the Supplementary for reference.

Here, we describe some aspects of, and the background to, the temporal transformation relevant to the livelihoods and HH incomes of frontier villagers between 2003 and 2012: livelihood-related activities, subdivided into three categories, comparing the total number of HHs engaged in each activity; average $\mathrm{HH}$ incomes and the amount and proportion of income obtained from each activity; and average $\mathrm{HH}$ income distributions in 2003 and 2012, subdivided into 10 strata, as well as the characteristics of those with the lowest and highest $25 \%$ of HH incomes.

\section{Results}

\subsection{Proportion of HHs Engaged in Each Activity and Profiles of Changes}

Table 1 shows the proportion of HHs, in 2003 and 2012, engaged in activities subdivided into three categories: agricultural production, forest-product collection and fishing/wage labor and business. The categories include two, four and three types of activities, respectively.

In both years, almost all HHs in the villages were engaged in agricultural production involving "rice and/or upland crop cultivation" (Table 1), making these the primary vocational activities in both 2003 and 2012. However, many villagers engaged in other activities in addition to cultivation, particularly in 
2012. NTFP collection activities, including "resin gathering", were important in 2012, as well as 2003, although the engagement ratio decreased slightly over the nine-year period. The proportion of members involved in "wage labor" increased greatly over this period. A large percentage of HHs were engaged in "wage labor" in 2012, primarily planting and harvesting cassava and, to a lesser extent, rice production and timber harvesting. Additionally, more than $30 \%$ of HHs engaged in "business" in 2012. Specifically, the activities included grocery sales, agricultural and NTFP brokerage, tractor cultivation and land renting.

Table 1. Proportion of households (HHs) engaged in each activity in 2003 and 2012 subdivided into three categories.

\begin{tabular}{|c|c|c|c|}
\hline $\begin{array}{c}\text { Target Year } \\
\text { Activity }\end{array}$ & & $\begin{array}{c}2003^{1} \\
(N=85) \\
(\%)\end{array}$ & $\begin{array}{c}2012^{2} \\
(N=146) \\
(\%)\end{array}$ \\
\hline \multirow{2}{*}{ Agricultural Production } & Rice/upland farming & 94 & 97 \\
\hline & Livestock raising & 59 & 69 \\
\hline \multirow{4}{*}{ Forest-product Collection } & Resin gathering & 72 & 61 \\
\hline & Fuel-wood collection & 79 & $\mathrm{NA}^{3}$ \\
\hline & $\begin{array}{l}\text { Other NTFP collection } \\
\text { (including wildlife) }\end{array}$ & 69 & 64 \\
\hline & Logging & 4 & 7 \\
\hline \multirow{2}{*}{ Fishing/Wage Labor } & Fishing & 39 & $\mathrm{NA}^{4}$ \\
\hline & Wage labor & 12 & 64 \\
\hline Business 5 & $\begin{array}{l}\text { Grocer, broker, } \\
\text { tractor cultivation, etc. }\end{array}$ & $\mathrm{NA}^{5}$ & 32 \\
\hline
\end{tabular}

${ }^{1}$ Source: McKenny et al. [20]; ${ }^{2}$ source: authors' survey in 2013 (unpublished data); ${ }^{3}$ all HHs in the survey area use fuel wood for cooking; thus, we omitted this activity from the items included in our survey to save time; only exceptional HHs, e.g., those consisting of aged and sick persons, may obtain fuel wood from their children, relatives and neighbors throughout the year; ${ }^{4}$ because there is no sea, lake, river or large pond near or in the study area, no HHs engaged in "fishing" as a primary occupation; however, even today, some HHs are likely to practice this activity in streams and their paddies for $\mathrm{HH}$ consumption; one reason for our results for "fishing" activities may be our use of the Khmer word for "occupation" in the relevant part of the questionnaire; ${ }^{5}$ McKenny et al. [20] included "business" in the part of their questionnaire that asked about HH activities; however, "business" was not included in the activity items in their table showing the survey results for $\mathrm{HH}$ activities; we do not know the reason for this omission; we present the results for "business" activities obtained by our questionnaire survey, which was designed in reference to McKenny et al. [20].

According to village leaders, wages are not necessarily paid to all outside labor, even today. When more labor is required than can be provided by family and relatives, a small proportion is performed via conventional exchange labor. However, demand for "wage labor" in villages has increased notably in the last decade with the expansion of commercial crops, particularly cassava. Furthermore, the reason that a third of HHs engaged in "business" activities was partly related to the expansion of commercial crop cultivation. Notably, tractor cultivation increased.

Table 2 compares HHs that were engaged in "wage labor" in 2012 with those that were not, based on $\mathrm{HH}$ holding ratios and the statistical characteristics of paddy and upland farm holding areas per $\mathrm{HH}$. As the land used for these two activities is the most important asset of villagers in this district, these land 
categories are adequate indicators of the villagers' assets. Considering the statistical information shown in Table 2, the differences between these groups are not large, assuming that a few individuals control large areas of land and that there are many landless peasants in these three frontier villages. In fact, only one $\mathrm{HH}$ had no agricultural land at all, and the top $10 \%$ of land holders together owned approximately a quarter of all arable land in the study area.

Table 2. Holding ratios and areas of farming fields of HHs engaged and not engaged in wage labor in 2012.

\begin{tabular}{lcc}
\hline \multicolumn{1}{c}{ Target Year } & \multicolumn{2}{c}{$\mathbf{2 0 1 2}(\mathbf{1 , 2}$} \\
$(\boldsymbol{N = \mathbf { 1 4 6 } )}$ \\
\hline \multicolumn{1}{c}{ Land Holding } & $\begin{array}{c}\text { Wage labor HHs } \\
(\boldsymbol{N}=\mathbf{9 3})\end{array}$ & $\begin{array}{c}\text { Non-wage labor HHs } \\
(\boldsymbol{N}=\mathbf{5 3})\end{array}$ \\
\hline Paddy holding ratio (\%) & 69 & 75 \\
Area (ha) & & \\
Mean & 0.8 & 1.2 \\
SD & 0.8 & 1.6 \\
Minimum & 0 & 0 \\
Median & 0.5 & 1 \\
Maximum & 4 & 10 \\
\hline Upland farm holding ratio (\%) & 96 & 98 \\
Area (ha) & & \\
Mean & 3.2 & 4.1 \\
SD & 2.5 & 3.7 \\
Minimum & 0 & 0 \\
Median & 3 & 4 \\
Maximum & 15 & 24 \\
\hline
\end{tabular}

${ }^{1}$ Source: authors' survey in 2013 (unpublished data); ${ }^{2}$ statistical differences in paddy and upland farm holding areas between the two groups were examined by a two-sided Wilcoxon rank-sum test using R Commander software (Version 3.1.1) [23]; $p$-values were 0.31 for paddy holding areas and 0.12 for upland farm holding areas; thus, the differences in the areas of the two holding types were not significant.

\subsection{Average HH Income and Income Sources}

Table 3 shows the changes between 2003 and 2012 in average $\mathrm{HH}$ incomes and the amounts and percentages from each income source. The values for 2012 are adjusted for the influence of inflation using the average Consumer Price Index (CPI) of Cambodia in 2003 and 2012. This table shows how $\mathrm{HH}$ income from each source changed, as well as the source of the increase in mean total HH income during the study period.

The increases were derived primarily from higher incomes from the cultivation of "other crops" and "business/wage labor." The contribution of "other crops" to the average total HH income was $12 \%$ in 2003, much smaller than that of "rice," "resin" and "other NTFPs". By contrast, the contribution of "other crops" was 43\% in 2012. Similarly, the "business/wage labor" proportion was very small in 2003, but increased notably by 2012. The combined income from the cultivation of "other crops" and 
"business/wage labor" comprised two-thirds of the average total HH income in 2012. The income contribution of "rice" declined during this period.

Cassava was the most extensively planted of "other crops". Cashew nuts were the next most planted, but occupied much smaller areas. These crops were planted for sale rather than HH consumption. In this area, cashew nuts were introduced from the beginning of the 2000s and cassava from the mid-2000s. Currently, the commune of which this study area is a part is one of the fastest growing centers, especially for cassava production, in Cambodia [24]. The harvested cassava is sent to Thailand, Vietnam and Phnom Penh via purchase agents for processing into animal feed and bio-ethanol $[25,26]$.

Table 3. Average total HH incomes and income sources in 2003 and 2012.

\begin{tabular}{|c|c|c|c|c|}
\hline \multirow{2}{*}{$\begin{array}{c}\text { Target Year } \\
\text { Source of Income }\end{array}$} & \multicolumn{2}{|c|}{$\begin{array}{c}2003^{1} \\
(N=85)\end{array}$} & \multicolumn{2}{|c|}{$\begin{array}{r}2012^{2} \\
(N=146)\end{array}$} \\
\hline & $\begin{array}{l}\text { Mean } \\
\text { (USD) }\end{array}$ & $\begin{array}{c}\text { Percent of } \\
\text { total }(\%)\end{array}$ & $\begin{array}{r}\text { Mean } \\
\text { (USD) }\end{array}$ & $\begin{array}{c}\text { Percent of } \\
\text { total }(\%)\end{array}$ \\
\hline Rice & 199 & 37 & 93 & 10 \\
\hline Other crops & 66 & 12 & 412 & 43 \\
\hline Livestock & 32 & 6 & 29 & 3 \\
\hline Resin & 116 & 22 & 156 & 16 \\
\hline Wildlife & 20 & 4 & 27 & 3 \\
\hline Other NTFP & 91 & 17 & 3 & 0 \\
\hline Logging & $\mathrm{NA}^{3}$ & - & 11 & 1 \\
\hline Business/wage labor & 9 & 2 & $\begin{array}{r}226 \\
(176 / 50)^{4}\end{array}$ & 24 \\
\hline Fishing & 4 & 1 & $\mathrm{NA}^{5}$ & - \\
\hline Total & 538 & 100 & $957^{6}$ & 100 \\
\hline
\end{tabular}

${ }^{1}$ Source: McKenny et al. [20]; the report contained detailed values for only total average HH income, each source's average $\mathrm{HH}$ income, median total $\mathrm{HH}$ income and total average $\mathrm{HH}$ income for each decile; therefore, we did not perform statistical comparisons of the incomes in 2003 and 2012; the median total HH income in 2003 was 492 USD [20]; the total average $\mathrm{HH}$ income in 2003 is shown for each decile in the form of a figure and a comparison with 2012; ${ }^{2}$ source: authors' survey in 2013 (unpublished data); the income values for 2012 are adjusted for inflation between 2003 and $2012(2003=1 ; 2012=1.789)$; we calculated the value 1.789 for 2012 by using the following formula: ((average CPI in 2012/average CPI in 2003) - 1 )+ 1. Average CPI (Consumer Prices Index) values for Cambodia for both years were obtained from http://www.econstats.com/weo/CKHM.htm (accessed on 23 September 2014). However, the value for 2012 was taken from the forecast issued by the International Monetary Fund (IMF); ${ }^{3}$ in the table presenting HH activities, McKenny et al. [20] reported that 4\% of all studied HHs engaged in logging, yet they reported no concrete income values for logging in their table showing average $\mathrm{HH}$ incomes; ${ }^{4}$ in the table showing average HH incomes, McKenny et al. [20] treated "business and wage labor" as a category. Therefore, our style conformed to that used by McKenny et al. [20]; additionally, we present the values for "business" and "wage labor" for the purposes of clarity; ${ }^{5}$ see Note 4 , Table $1 ;{ }^{6}$ important statistical values other than the mean for total $\mathrm{HH}$ incomes in 2012 were as follows: minimum $=-73$ USD, 25th quartile $=385$ $\mathrm{USD}$, median $=605 \mathrm{USD}, 75$ th quartile $=1086 \mathrm{USD}$ and $\operatorname{maximum}=10,141 \mathrm{USD}$. 
In addition to the expansion of "wage labor," there was noteworthy growth in the proportion of income derived from these cash crops. This indicates an underlying transformation of the production systems in the study area from subsistence-dominated to commodity-dominated. In 2003, many HHs earned cash from moneymaking products, such as "resin" gathered from Dipterocarpaceae trees, most of which was used as a waterproof coating material for wooden boats operated on Tonlé Sap Lake and inshore in the country. However, the proportion of the average total HH income obtained from "resin," the product that yielded the most cash in 2003, was only half as much as that from the cultivation of "other crops" in 2012. The striking expansion of cash crops, which had a larger market beyond the region and country, is likely to have shifted the structure of agriculture, i.e., the primary vocational activity of most villagers, in this remote area of a least-developed country, although more detailed aspects than average incomes should be explored to understand properly such a transformation over the decade.

\subsection{Comparison among and between HH Income Groups}

Figure 4 compares the average total $\mathrm{HH}$ income distributions, subdivided into 10 strata, from the lowest to the highest groups, in 2003 and 2012. The values in 2012 are adjusted for inflation over the same period. The differences in decay and growth in each stratum over the nine years suggest an imbalance in the underlying transformation of the local production system, which is invisible in the simple comparison of average $\mathrm{HH}$ incomes in Table 3. What underlies the variation among strata in average HH incomes? Tables 4 and 5 focus on the lowest and highest $25 \%$ of HHs grouped by income in 2012 to analyze the details of this imbalance.

Figure 4. Changes in income distribution between 2003 and 2012 (by 10\%).

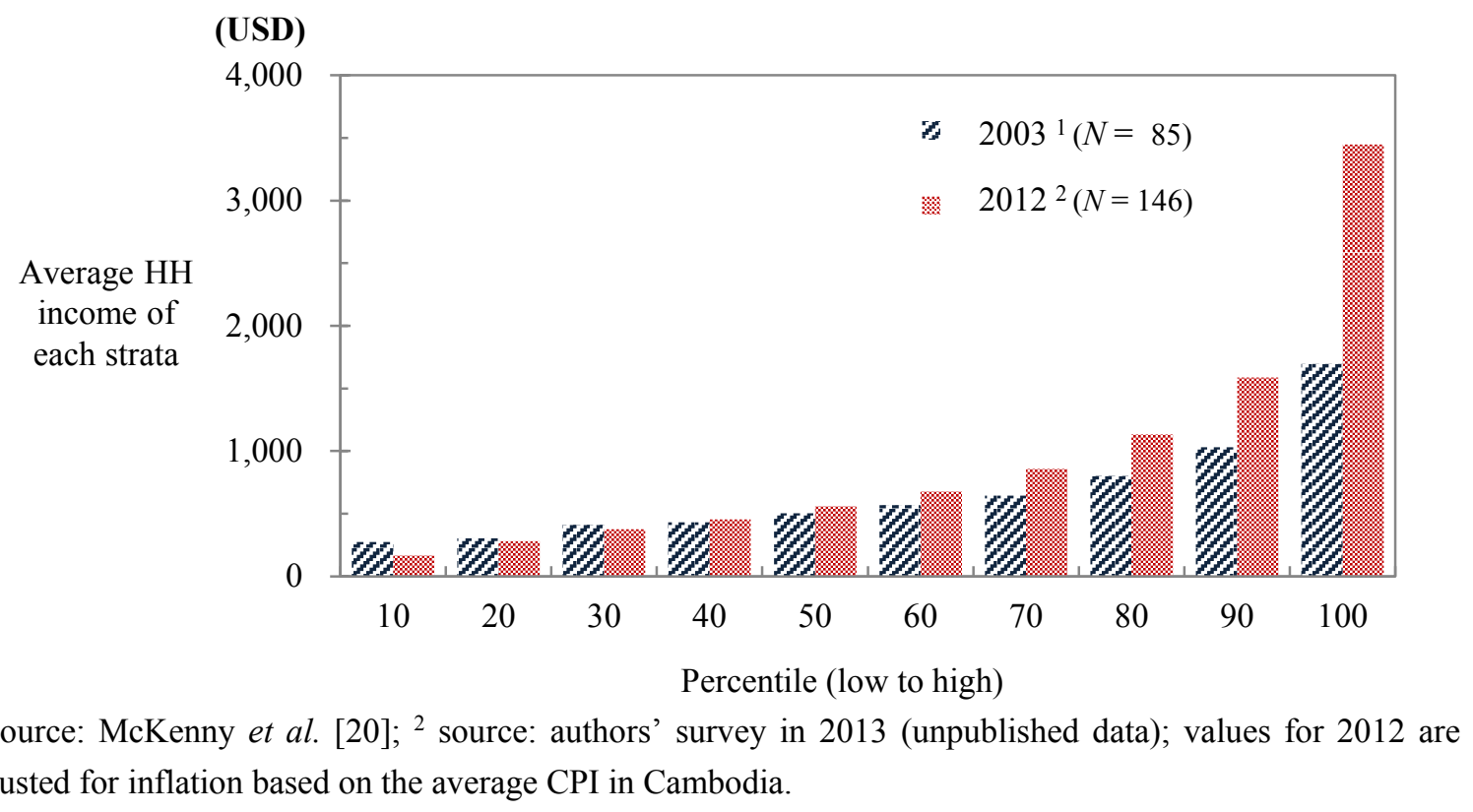

Table 4 focuses on the average total HH incomes of these two groups, showing the sources and percentages of the various factors that contributed to total HH incomes in 2012. The values shown under "2012" are adjusted for inflation, whereas the "2012a" values are nominal incomes without any adjustment. Table 4 shows a difference in the proportion of income acquired from the cultivation of 
"other crops" by the HHs in these two groups. The group with the highest incomes earned over half of their average total $\mathrm{HH}$ income from the cultivation of "other crops," over five times the percentage for those with the lowest incomes. Moreover, three-quarters of the average total HH income of the high earners came from the cultivation of "other crops" and "business/wage labor," which reflects the underlying transition to a commodity-dominated production system in the study area, as suggested by the overall average HH incomes in 2012 (Table 3). By contrast, the HH income composition of the lowest $25 \%$ of earners was very different and resembled the composition of average $\mathrm{HH}$ incomes in 2003 , except for the proportion from "business/wage labor."

Table 4. Average total HH incomes and income sources in 2012 for the lowest and highest $25 \%$ of HHs.

\begin{tabular}{|c|c|c|c|c|c|c|}
\hline \multirow{3}{*}{$\begin{array}{c}\text { Target Year } \\
\\
\text { Source of } \\
\text { Income }\end{array}$} & \multicolumn{4}{|c|}{$\begin{array}{c}2012^{1} \\
(N=146)\end{array}$} & \multicolumn{2}{|c|}{$\begin{array}{c}2012 a^{1} \text { (Nominal } \\
\text { incomes) } \\
(N=146) \\
\end{array}$} \\
\hline & \multicolumn{2}{|c|}{$\begin{array}{l}\text { Lowest } 25 \%^{2} \\
\qquad(N=37)\end{array}$} & \multicolumn{2}{|c|}{$\begin{array}{l}\text { Highest } 25 \%^{2} \\
\qquad(N=37)\end{array}$} & \multirow{2}{*}{$\begin{array}{c}\begin{array}{c}\text { Lowest } \\
25 \% \\
(N=37)\end{array} \\
\begin{array}{c}\text { Mean } \\
\text { (USD) }\end{array}\end{array}$} & \multirow{2}{*}{ 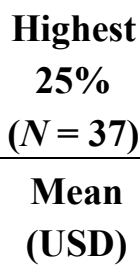 } \\
\hline & Mean (USD) & $\begin{array}{c}\text { Percent of } \\
\text { total (\%) }\end{array}$ & Mean (USD) & $\begin{array}{r}\text { Percent of } \\
\text { total }(\%)\end{array}$ & & \\
\hline Rice & 52 & 21 & 117 & 5 & 93 & 210 \\
\hline Other crops * & 22 & 9 & 1,199 & 53 & 39 & 2,146 \\
\hline Livestock * & 0 & 0 & 81 & 3 & 0 & 145 \\
\hline Resin * & 75 & 30 & 266 & 12 & 134 & 475 \\
\hline Wildlife & 21 & 8 & 18 & 1 & 38 & 31 \\
\hline Other NTFP & 3 & 1 & 7 & 0 & 5 & 13 \\
\hline Logging & 2 & 1 & 17 & 1 & 4 & 31 \\
\hline $\begin{array}{l}\text { Business */ } \\
\text { wage labor * }\end{array}$ & $\begin{array}{r}76 \\
(37 / 39)^{3}\end{array}$ & 30 & $\begin{array}{r}562 \\
(520 / 42)^{3}\end{array}$ & 25 & 135 & 1,005 \\
\hline Fishing & NA & - & NA & - & NA & NA \\
\hline Total * & $251^{4}$ & 100 & $2,267^{4}$ & 100 & 448 & 4,056 \\
\hline
\end{tabular}

${ }^{1}$ Source: authors' survey in 2013 (unpublished data); the income values for 2012 are adjusted for inflation between 2003 and 2012; for the method, see Note 2 in Table 3; the "2012a" values are nominal incomes without any adjustment; ${ }^{2}$ statistical differences in the sources of income and the total incomes of the two groups were examined by a two-sided Wilcoxon rank-sum test using R Commander software (Version 3.1.1) [23]; for "business/wage labor," we tested "business" and "wage labor" separately; differences for which $p<0.05$ were considered significant; * indicates significance; ${ }^{3}$ see Note 4 , Table $3 ;{ }^{4}$ important statistical values other than the mean for total $\mathrm{HH}$ incomes are as follows: for the lowest $25 \%$ of HHs, minimum $=-73 \mathrm{USD}$, 25th quartile $=216 \mathrm{USD}$, median $=262$ USD, 75th quartile $=305$ USD and maximum $=385$ USD; for the highest $25 \%$ of HHs, minimum $=1092$ USD, 25th quartile $=1459$ USD, median $=1635$ USD, 75th quartile $=2441$ USD and maximum $=10,141$ USD. 
Table 5 focuses on the characteristics of the 2012 upland farm holdings of the lowest and highest 25\% of HHs by income and the differences in cassava and cashew nut cultivation in 2012 in the same two groups. The lowest $25 \%$ of earners had much less income from cultivation of these cash crops, especially cassava, than did the highest $25 \%$ of earners, due primarily to lower benefits per $\mathrm{HH}$ and smaller farm holdings, rather than to a lack of attempts at commercial cultivation. Furthermore, Table 5 indicates that the majority of the lowest $25 \%$ of earners had already started to shift toward a commodity-dominant production system, although to a lesser extent than the highest $25 \%$ of earners.

Table 5. Upland farm holdings and cultivation of two major cash crops in 2012 for the lowest and highest $25 \%$ of HHs.

\begin{tabular}{|c|c|c|}
\hline \multirow{2}{*}{$\begin{array}{c}\text { Target Year } \\
\text { Land Holding/ } \\
\text { Cultivation }\end{array}$} & \multicolumn{2}{|c|}{$\begin{array}{l}2012 a^{1,2} \\
(N=146)\end{array}$} \\
\hline & $\begin{array}{c}\text { Lowest } 25 \% \\
(N=37)\end{array}$ & $\begin{array}{c}\text { Highest } 25 \% \\
\quad(N=37)\end{array}$ \\
\hline Upland farm holding HHs (\%) & 97 & 100 \\
\hline \multicolumn{3}{|l|}{ Area (ha) * } \\
\hline Mean & 2.6 & 5.4 \\
\hline $\mathrm{SD}$ & 1.8 & 4.3 \\
\hline Minimum & 0.0 & 1.0 \\
\hline Median & 2.0 & 4.0 \\
\hline Maximum & 9.0 & 24.0 \\
\hline Cassava cultivating HHs (\%) & 65 & 92 \\
\hline \multicolumn{3}{|l|}{ Value per HH (USD) } \\
\hline Input cost: mean (median) * & $191(0)$ & $855(230)$ \\
\hline Output value: mean (median)* & $259(150)$ & $2,750(1,500)$ \\
\hline Benefit: mean (median) $*$ & $68(0)$ & $1,895(900)$ \\
\hline Cashew nut cultivating HHs (\%) & 22 & 32 \\
\hline \multicolumn{3}{|l|}{ Value per HH (USD) } \\
\hline Input cost per HH: mean (median) & $35(0)$ & $98(0)$ \\
\hline Output value per HH: mean (median) & $5(0)$ & $168(0)$ \\
\hline Benefit per HH: mean (median) & $-30(0)$ & $70(0)$ \\
\hline
\end{tabular}

\footnotetext{
${ }^{1}$ Source: authors' survey in 2013 (unpublished data); the 2012a values for input cost, output value and benefits are not adjusted; ${ }^{2}$ statistical differences between the two groups for upland farm holding areas and input cost, output value and benefit per $\mathrm{HH}$ for cassava and cashew nut cultivation were examined with a two-sided Wilcoxon rank-sum test using R Commander software (Version 3.1.1) [23]; differences for which $p<0.05$ were considered significant; $*$ indicates significance.
}

\section{Discussion}

Previous research and discussion have identified the major drivers and policies promoting or preventing deforestation in tropical countries. The expansion of commercial crop production has been one of the most cited factors [27-33], yet continued deforestation suggests that the countermeasures have either not been implemented or have been unsuccessful. Expansion into forest areas has been driven 
by both large-scale developers and small-scale farmers [15,21,22]. Large-scale development needs to be addressed by policy reform at the governmental level, but this faces substantial challenges, even under a global REDD+ system, due to deep-rooted problematic structures in the political economy of each country [34]. Expansion by small-scale farmers can be addressed locally, although policy support at the national level, such as curbing both any further influx of HHs and the extension of roads into forest areas, is needed [35]. As a result, REDD+ projects to date have targeted rural communities rather than large businesses [15]. However, the realities of the changes in $\mathrm{HH}$ income, including the changes in its structure and in livelihood activities, which this case study has clarified, indicate the existence of significant hurdles to motivating community members to truly embrace alternative land use practices in particular project areas.

In the frontier areas, a key factor potentially enabling the incentives for community members to alter ongoing land use practices is the actual and expected profits that each member gains and expects to gain from the expansion of commercial crop cultivation. At this study site, expansion into forest areas has given considerable benefits to the local population through increases in total $\mathrm{HH}$ incomes, although there have been wide differences in the monetary returns among HHs. This could discourage conservation of forest land, as expansion provides an incentive for village HHs, especially the poorer HHs, to seek larger and better farmland within uncultivated forest land.

In just a decade, the explosive expansion of commercial cassava cultivation has transformed the production system of many villagers from subsistence to commodity dominant. This is true even for lower income HHs. Compared with higher income classes, the lower income classes largely have smaller-scale cassava farms with lower benefits. Therefore, expansion of arable land into land with greater potential in terms of commercial agricultural production is an economically rational option for lower income HHs, which have less capital to increase their benefit from the cultivation of cash crops on current agricultural land. Furthermore, two structural characteristics of the study villages may encourage the lower income HHs to favor this option: a society consisting of independent farmers, who have experienced many HHs clearing forests and expanding arable lands, as well as a society with a moderate income disparity. These two aspects (the former suggested in Table 2) are likely to become the factors that motivate some HHs to expand their agricultural land into uncultivated forest land.

REDD+ benefit sharing or support in frontier areas must persuade community members to reject incentives for forest clearing and arable land expansion if the aim is truly to curb deforestation. As Angelsen and Rudel [11] pointed out, one valid option for supporting frontier communities, which REDD+ project developers could adopt at the local rather than the governmental level, involves encouraging "intensive" agriculture on existing cultivated land to garner profits from such land and disincentivize further expansion of arable land into forest areas. This option is possible because of modern agricultural technology. During the implementation phase, however, some intractable dilemmas and challenges in terms of effectiveness and efficiency, derived from changes in $\mathrm{HH}$ income, income structure and livelihood activity in the study area, can be expected to arise.

As repeatedly mentioned, incentives for community members to engage in alternative land use are affected not only by actual, but also by expected profits. Considering the nature of such incentives, the level of profits that would satisfy many members could be beyond real incomes, corresponding to the incomes of the higher class in the same community and other rural regions. This is an element that pushes up the cost of the support offered by the REDD+ project. To reduce this expense, concentration and 
differential allocation of support resources, especially to the lower income class, is needed. The sorting of HHs will be a difficult operation, because there are no explicit social identifiers that can easily be perceived by outsiders, except in societies where caste and landlord-tenant systems remain. Besides, unconsidered support for intensive farming that does not build on the structures of income and livelihood activities in communities could have the opposite effect on forest conservation. For example, ill-considered offers and donations of particular agricultural machines, e.g., tractors and harvesters, to communities may motivate some HHs to engage in forest clearing and arable-land expansion, as such machines deprive the HHs of business or wage-labor opportunities. Some income-opportunity losers, such as tractor-cultivation entrepreneurs and wage laborers, may open new land as a substitute for their lost income opportunities if they are unable to find alternative income sources.

\section{Conclusions}

Because of the wide, imbalanced and complicated effects that the commodity-dominant production system has had on community members in the frontier areas, REDD+ support for sustainable land use and people's livelihoods must increase in complexity, sophistication and cost compared with that provided in areas where the subsistence production system still dominates, as it did in the study area a decade ago. If incentives for alternative land use are misdirected or inadequate, REDD+ benefit sharing will not fulfill its function of halting deforestation. This suggests that REDD+ projects in frontier areas can theoretically achieve maximum gains in the forest carbon balance, but they face more difficulties and challenges to achieve success.

\section{Acknowledgments}

The authors wish to thank many villagers in the study site, Prom Tola, Motoe Miyamoto, Tetsuya Michinaka, Norimasa Takayama and Hao Gong for providing information regarding their households, methodological suggestions and GIS data preparation. The authors also thank three anonymous reviewers for their comments and suggestions.

\section{Conflicts of Interest}

The authors declare no conflict of interest.

\section{References}

1. Peskett, L.; Huberman, D.; Bowenjones, E.; Edwards, G.; Brown, J. Making REDD Work for the Poor; ODI: London, UK, 2008; p. 78.

2. World Bank. Rethinking Forest Partnerships and Benefit Sharing: Insights on Factors and Context That Make Collaborate Arrangements Work for Communities and Landowners; The World Bank: Washington, DC, USA, 2009; p. 78.

3. Gregersen, H.; Lalany, H.; Karsenty, A.; White, A. Does the Opportunity Cost Approach Indicate the Real Cost of REDD+? Rights and Realities of Paying for REDD+; Rights and Resources Initiative: Washington, DC, USA, 2010; p. 23. 
4. Lindhjem, H.; Aronsen, I.; Braten, K.; Gleinsvik, A. Experience with Benefit Sharing: Issues and Options for REDD-Plus; Econ Poyry: Oslo, Norway, 2011; p. 116.

5. Costenbader, J. REDD+ Benefit Sharing: A Comparative Assessment of Three National Policy Approach; UN-REDD programme: Geneva, Switzerland, 2011; p. 58.

6. Peskett, L. Benefit Sharing in REDD+: Exploring the Implications for Poor and Vulnerable People; World Bank and REDD-net: Washington, DC, USA, 2011; p. 40.

7. PwC (PricewaterhouseCoopers). Assessing Options for Effective Mechanisms to Share Benefit: Insights for REDD+ Initiatives; Program on Forests (PROFOR): Washington, DC, USA, 2012; p. 160.

8. Enright, A.; McNally, R.; Sikor, T. An Approach to Designing pro-Poor Local REDD+Benefit Distribution Systems: Lessons from Vietnam; SNV: Hanoi, Vietnam, 2012; p. 25.

9. Pham, T.T.; Brockhaus, M.; Wong, G.; Dung, L.N.; Tjajadi, J.S.; Loft, L.; Luttrell, C.; Assembe, S. Approaches to Benefit Sharing: A Preliminary Comparative Analysis of 13 REDD+ Countries; Working Paper 108; CIFOR: Bogor, Indonesia, 2013; p. 69.

10. Luttrell, C.; Loft, L.; Gebara, M.; Keweka, D.; Brockhaus, M.; Angelsen, A.; Sunderlin, D. Who should benefit from REDD+? Rationale and realities. Ecol. Soc. 2013, 18, 52.

11. Angelsen, A.; Rudel, T. Designing and implementing effective REDD+ policies: A forest transition approach. Rev. Environ. Econ. Policy 2013, 7, 91-113.

12. Chomitz, K.; Buy, P.; Luca, G.; Thomas, T.; Wertz-Kanounnikoff, S. At Loggerheads? Agricultural Expansion, Poverty Reduction, and Environment in the Tropical Forests; World Bank Policy Research Report; World Bank: Washington, DC, USA, 2007; p. 284.

13. Pacheco, P.; Aguilar-Støen, M.; Borner, J.; Etter, A.; Putzel, L.; Diaz, M. Landscape transformation in Tropical Latin America: assessing trends and policy implications for REDD+. Forests 2011, 2 , $1-29$.

14. Mai Ndombe REDD+; A Joint Project of ERA and WILDLIFE WORKS. Project Design Document, Validated to the Climate, Community, and Biodiversity Standards, 2nd ed.; Prpich, L., Ed.; 2012; p. 145. Available online: https://s3.amazonaws.com/CCBA/Projects/Mai_Ndombe_REDD_ Project/Mai+Ndombe+Final+CCB+PDD.pdf (accessed on 23 September 2014).

15. Scheyvens, H.; Sagara, M. REDD+ Projects: A Review of Selected REDD+ Project Designs; IGES: Kanagawa, Japan, 2013; p. 133.

16. Scheyvens, H.; Gilby, S.; Yamanoshita, M.; Fujisaki, T.; Kawasaki, J. REDD+ Projects: Snapshots of Selected REDD+ Project Designs-2013; IGES: Kanagawa, Japan, 2014; p. 108.

17. Blackburn, T. Oddar Meanchey REDD+ Project: Report on 2010 Household Survey Pact-Cambodia; Pact: Phnom Penh, Cambodia, 2011; p. 101.

18. GTZ. Socio-Economic Baseline for the REDD+ Project Sites in Southern Leyte, Philippines; GTZ: Manila, Philippines, 2012; p. 134.

19. Movik, S.; Birikorang, G.; Enright, A.; Kajembe, G.; Lima, L. Socio-Economic Conditions in REDD+ Pilot Areas: A Synthesis of Five Baseline Survey; IIED: London, UK, 2012; p. 38.

20. McKenny, B.; Chea, Y.; Tola, P.; Evans, T. Focusing on Cambodia's High Value Forests: Livelihoods and Management; CDRI and WCS: Phnom Penh, Cambodia, 2004; p. 120. 
21. Matsuura, T.; Miyamoto, A.; Kurashima, T.; Sano, M.; Chann, S.; Pak, C.; Leng, C. Spatial characteristics of recent deforestation and the effects of zoning in the upper Chinit river basin, central Cambodia. In Proceedings of 8th International Workshop on Forest Watershed Environment Research in Cambodia, Phnom Penh, Cambodia; Shimizu, A., Chann, S., Sawada, H., Ohnuki, Y., Tamai, K., Eds.; Forestry and Forest Products Research Institute, Japan and Forestry Administration Cambodia: Tsukuba, Japan, 2012; pp. 41-44.

22. Müller, F. Commune-Based Land Allocation for Poverty Reduction in Cambodia: Achievements and Lessons Learned from the Project: Land Allocation for Social and Economic Development (LASED); World Bank: Washington, DC, USA, 2012; p. 23.

23. R Core Team. R: A Language and Environment for Statistical Computing; R Foundation for Statistical Computing: Vienna, Austria, 2014. Available online: http://www.R-project.org/ (accessed on 23 September 2014)

24. National Institute of Statistics. Census of Agriculture in Cambodia 2013: Preliminary Report; Ministry of Planning: Phnom Penh, Cambodia, 2014; p. 33.

25. Hing, V.; Thun, V. Agricultural Trade in the Greater Mekong Sub-Region: The Case of Cassava and Rubber in Cambodia; CDRI: Phnom Penh, Cambodia, 2009; p. 59.

26. Dao, C. Business Process Analysis: Export of Cassava and Maize in Cambodia; ESCAP: Bangkok, Thailand; p. 79.

27. Kaimowitz, D.; Angelsen, A. Economic Models of Tropical Deforestation: A Review; CIFOR: Bogor, Indonesia, 1998; p. 139.

28. Geist, H.; Lambin, E. What Drives Tropical Deforestation? A Meta-Analysis of Proximate and Underlying Causes of Deforestation Based on Subnational Case Study Evidence; LUCC International Project Office: Louvain-la-Neuve, Belgium, 2001; p.116.

29. Wunder, S. Policy options for stabilizing the forest frontier: A global perspective. In Land Use, Nature Conservation and the Stability of Rainforest Margins in Southeast Asia; Gerold, G., Fremerey, M., Guhardja, E., Eds.; Springer: Berlin, Germany, 2004; pp. 3-25.

30. Angelsen, A. Chapter 10: Policy options to reduce deforestation. In Realising REDD+: National Strategy and Policy Options; Angelsen, A. Ed.; CIFOR: Bogor, Indonesia, 2009; pp. 125-138.

31. Leisz, S.; Kono, Y.; Fox, J.; Yanagisawa, M.; Rambo, T. Land use changes in the upland of Southeast Asia: Proximate and distant causes: Introduction. Southeast Asian Studies. 2009, 47, 237-243.

32. Miyamoto, M. The causes of tropical deforestation: Rethinking the effects of shifting cultivation, population growth, and road construction (in Japanese with English abstract). J. Jpn. For. Soc. 2010, 92, 226-234.

33. Michinaka, T.; Miyamoto, M.; Yokota, Y.; Sokh, H. Factors affecting forest area changes in Cambodia: An econometric approach. J. Sustain. Development. 2013, 6, 12-25.

34. Gregorio, D.M.; Brockhaus, M.; Cronin, T.; Muharrom, E. Politics and power in national REDD+ policy process. In Analysing REDD+: Challenges and Choices; Angelsen, A., Brockhaus, M., Sunderlin, W., Verchot, L., Eds.; CIFOR: Bogor, Indonesia, 2012; pp. 69-90. 
35. Miyamoto, M. Forest conversion to rubber around Sumatran villages in Indonesia: comparing the impacts of road construction, transmigration projects and population. For. Policy Econ. 2006, 9 , $1-12$.

(C) 2014 by the authors; licensee MDPI, Basel, Switzerland. This article is an open access article distributed under the terms and conditions of the Creative Commons Attribution license (http://creativecommons.org/licenses/by/4.0/). 